\title{
SISTEM PAKAR DETEKSI DINI HIV/AIDS DENGAN METODE FORWARD CHAINING DAN CERTAINTY FACTOR
}

\section{EXPERT SYSTEM OF HIVIAIDS EARLY DETECTION WITH FORWARD CHAINING AND CERTAINTY FACTOR METHOD}

\author{
Bayu Adhi Pamungkas ${ }^{1}$, Apriade Voutama ${ }^{2}$, Betha Nurina Sari ${ }^{3}$, Susilawati ${ }^{4}$ \\ ${ }^{1234}$ Universitas Singaperbangsa Karawang \\ bayu.pamungkas17067@student.unsika.ac.id
}

\begin{abstract}
Every year the graph of the number of HIV cases in Indonesia continues to increase, but the number is still below the estimate due to the high stigma and discrimination that causes people to be reluctant to do HIV tests. To overcome this, an expert system is needed so that people can carry out initial HIV checks through their respective devices without the need to come to the clinic. The purpose of this research is to design, implement, and evaluate an expert system for early detection of HIV/AIDS using the forward chaining and certainty factor method. The research method used is ESDLC, which consists of the stages of assessment, knowledge acquisition, design, testing, and documentation. The results of the system evaluation carried out using a questionnaire to 50 respondents showed the results in terms of appearance had a percentage of $82.3 \%$ and in terms of benefits of $82.2 \%$ so it can be concluded that the system can be accepted by the community with a very strong interpretation.
\end{abstract}

Keywords: Expert System, HIV/AIDS, Forward Chaining, Certainty Factor, ESDLC.

\begin{abstract}
ABSTRAK
Setiap tahun grafik jumlah kasus HIV di Indonesia terus mengalami peningkatan, akan tetapi jumlah tersebut masih di bawah estimasi karena tingginya stigma dan diskriminasi yang menyebabkan masyarakat enggan untuk melakukan pemeriksaan HIV. Untuk mengatasi hal tersebut diperlukan sebuah sistem pakar sehingga masyarakat dapat melakukan pemeriksaan awal HIV melalui perangkat masing-masing tanpa perlu datang ke klinik. Tujuan penelitian ini adalah untuk merancang, mengimplementasikan, dan mengevaluasi sistem pakar deteksi dini HIV/AIDS dengan menggunakan metode forward chaining dan certainty factor. Metode penelitian yang digunakan yaitu ESDLC, yang terdiri dari tahap penilaian, akuisisi pengetahuan, perancangan, pengujian, dan dokumentasi. Hasil evaluasi sistem yang dilakukan menggunakan kuesioner terhadap 50 responden menunjukan hasil dari segi tampilan memiliki persentase sebesar $82,3 \%$ dan dari segi manfaat sebesar $82,2 \%$ sehingga dapat disimpulkan bahwa sistem dapat diterima oleh masyarakat dengan interpretasi sangat kuat.
\end{abstract}

Kata Kunci: Sistem Pakar, HIV/AIDS, Forward Chaining, Certainty Factor, ESDLC.

\section{PENDAHULUAN}

Acquired Immune Deficiency Syndrome (AIDS) merupakan serangkaian gejala yang muncul karena infeksi yang disebabkan oleh Human Immunodeficiency Virus (HIV), yaitu virus yang menyerang leukosit sehingga sistem kekebalan tubuh manusia menurun (Kementerian Kesehatan RI, 2020). Untuk mengatasi pertambahan kasus infeksi HIV yang terus meningkat setiap tahunnya di seluruh dunia maka dibuat visi penanggulangan HIV secara global yang dideklarasikan pada tahun 2010 dengan nama three zeros, yang meliputi nol kasus infeksi baru, nol kasus kematian karena HIV/AIDS, dan nol diskriminasi terhadap Orang dengan HIV/AIDS (ODHA). Kemudian pada tahun 2015 three zeros dijadikan sebagai target dasar HIV pada agenda pembangunan berkelanjutan tahun 2030, dan untuk mencapai target tersebut maka Majelis Jenderal Perserikatan Bangsa-Bangsa (PBB) tahun 2016 menyampaikan deklarasi politik yang berisi target pencapaian sementara tahun 2020 yang isinya yaitu mengurangi kasus infeksi HIV menjadi kurang dari 500.000 pada tahun 2020, mengurangi angka kematian terkait AIDS menjadi kurang dari 500.000 kasus, serta menghilangkan diskriminasi serta stigma terhadap ODHA (UNAIDS, 2020). 
Berdasarkan data yang diperoleh dari UNAIDS (2020) diketahui bahwa jumlah pertambahan kasus infeksi baru HIV mencapai 1,7 juta pada tahun 2019, angka kematian terkait AIDS pada tahun 2019 mencapai 690 ribu kasus, dan di 25 negara kasus diskriminasi yang dilakukan oleh orang dewasa terhadap ODHA mencapai lebih dari 50\%. Data tersebut menunjukan bahwa target pencapaian penanganan kasus HIV/AIDS yang dideklarasikan masih belum tercapai.

Kementerian Kesehatan RI (2020), menyebutkan bahwa jumlah kasus HIV di Indonesia hingga tahun 2019 terus mengalami peningkatan, dimana jumlah kasus tertinggi terdapat pada tahun 2019. Namun, jumlah kasus HIV yang dilaporkan tersebut masih di bawah target yang telah diperkirakan sebelumnya, yaitu sekitar $65,5 \%$ dari target estimasi $90 \%$ Orang dengan HIV/AIDS (ODHA) pada tahun 2016 (Direktur Jenderal P2P, 2020). Salah satu faktor yang menyebabkan jumlah kasus HIV yang ditemukan di Indonesia masih di bawah target adalah karena tingginya stigma dan diskriminasi yang mayoritas dilakukan oleh kalangan remaja terhadap ODHA yang menyebabkan masyarakat dengan resiko tinggi enggan untuk melakukan pemeriksaan HIV sehingga berdampak langsung terhadap penurunan kesehatan ODHA (Situmeang et al., 2017).

Untuk mengatasi permasalahan tersebut perlu dibuat aplikasi yang memiliki kemampuan mendeteksi penyakit HIV seperti seorang ahli sehingga pengguna dapat melakukan pemeriksaan awal HIV/AIDS melalui perangkat masingmasing tanpa perlu mendatangi dokter secara langsung, aplikasi tersebut adalah sistem pakar. Menurut Arhami, sistem pakar adalah sebuah cabang artificial intelligence yang berfungsi membantu manusia untuk menyelesaikan berbagai permasalahan yang hanya dapat diselesaikan oleh pakar (Hayadi, 2016).

Terdapat dua buah metode yang digunakan pada sistem pakar ini, yaitu metode forward chaining serta metode certainty factor. Metode forward chaining merupakan metode inferensi yang bersifat data-driven, artinya fokus penalaran sistem akan dimulai dari data yang diketahui, selain itu metode ini akan menggunakan kaidah serta aturan inferensi yang ada untuk mendapatkan berbagai data yang dibutuhkan sehingga mendapat sebuah kesimpulan (Akil, 2017). Sedangkan metode certainty factor merupakan metode yang berfungsi untuk menghitung tingkat kepercayaan pakar terhadap hasil diagnosis yang diberikan oleh sistem. Kelebihan penggunaan metode certainty factor adalah metode ini sangat tepat apabila digunakan untuk menghitung nilai kepastian terhadap diagnosis suatu penyakit dan keakuratan data yang digunakan akan tetap terjaga karena perhitungan yang dilakukan hanya mengolah dua buah data dalam satu kali perhitungan (Iskandar, 2017).

Penelitian ini bertujuan untuk merancang, mengimplementasikan, serta melakukan evaluasi sistem pakar deteksi dini HIV/AIDS dengan metode forward chaining dan certainty factor.

\section{METODE}

Metode pengembangan perangkat lunak yang digunakan pada penelitian ini adalah dengan menggunakan metode Expert System Development Life Cycle (ESDLC). Tahapan ESDLC dapat dilihat pada gambar 1.

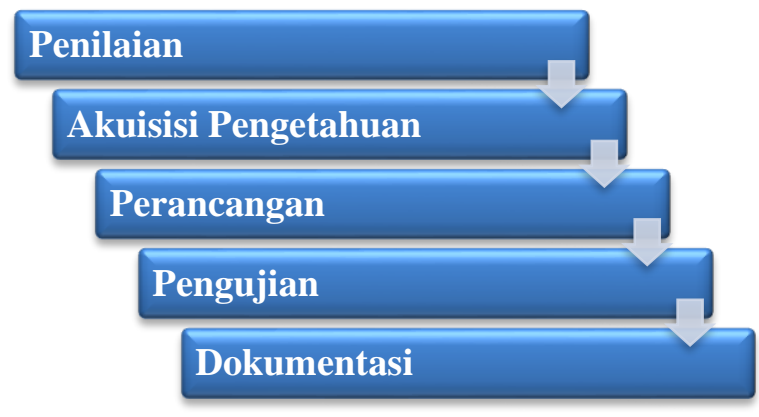

Gambar 1. Tahapan Expert System Development Life Cycle (ESDLC)

Menurut Durkin tahap penelitian dengan menggunakan metode Expert 
System Development Life Cycle (ESDLC) terdiri dari (Fajrin \& Destiani, 2016):

\section{Penilaian}

Pada tahap penilaian, proses yang dilakukan adalah melakukan analisis terhadap permasalahan yang ada dengan membaca berbagai macam literatur yang terkait dengan penyakit HIV/AIDS, kemudian dilanjutkan dengan melakukan analisis terhadap berbagai macam kebutuhan pengguna dan kebutuhan sistem.

\section{Akuisisi Pengetahuan}

Pada tahap ini dilakukan studi literatur dan wawancara terhadap pakar, serta melakukan representasi pengetahuan dengan menggunakan kaidah produksi untuk memberikan gambaran dalam suatu bentuk yang berbeda.

\section{Perancangan}

Proses pertama yang dilakukan pada tahap perancangan yaitu membuat desain arsitektur aplikasi dengan menggunakan Unified Modelling Language (UML). Menurut Rosa A.S. dan M. Shalahuddin, UML merupakan salah satu dari standar bahasa yang banyak digunakan untuk membuat visualisasi untuk berbagai macam kebutuhan (Voutama, 2018). Proses kedua yang dilakukan adalah dengan membuat desain arsitektur interface untuk membuat desain antarmuka dari sistem pakar deteksi dini HIV/AIDS. Langkah selanjutnya adalah proses implementasi sistem ke dalam bahasa pemrograman.

\section{Pengujian}

Tahap pengujian dilakukan untuk mengetahui apakah sistem yang telah berhasil diimplementasikan sesuai dengan rancangan sistem pakar yang telah dibuat. Apabila hasil pengujian menunjukan terdapat suatu bagian yang belum sesuai maka dapat dilakukan evaluasi sehingga sistem dapat bekerja sesuai dengan rancangan yang telah dibuat.

\section{Dokumentasi}

Dokumentasi adalah pengumpulan berbagai informasi yang dibutuhkan untuk mengoperasikan sistem pakar deteksi dini HIV/AIDS yang telah dibuat.

\section{HASIL DAN PEMBAHASAN}

Hasil dari penelitian yang dilakukan adalah sistem pakar deteksi dini HIV/AIDS dengan metode forward chaining dan certainty factor yang dibuat berbasis web. Berikut ini merupakan pembahasan mengenai tahapan penelitian yang telah dilakukan:

\section{Penilaian}

Pada tahap penilaian terdapat tiga jenis analisis yang dilakukan, yaitu:

a. Analisis Permasalahan

Analisis permasalahan dilakukan berdasarkan berbagai macam studi literatur. Berikut ini adalah kesimpulan yang dihasilkan dari proses analisis permasalahan yang telah dilakukan:

1) Salah satu faktor yang membuat jumlah kasus HIV yang dilaporkan masih di bawah target adalah karena tingginya stigma dan diskriminasi yang dilakukan oleh masyarakat kepada ODHA sehingga membuat orang dengan resiko tinggi terkena HIV/AIDS enggan untuk melakukan pemeriksaan HIV.

2) Kasus stigma dan diskriminasi yang terjadi di masyarakat sebagian besar dilakukan oleh kalangan remaja karena kurangnya pengetahuan terkait penyakit HIV/AIDS.

b. Analisis Kebutuhan Pengguna

Berbagai macam kebutuhan pengguna yang diperlukan pada sistem pakar ini antara lain adalah:

1) Membutuhkan halaman konsultasi untuk melakukan pemeriksaan awal HIV/AIDS.

2) Membutuhkan halaman hasil konsultasi untuk mengetahui hasil diagnosis pemeriksaan dengan disertai tingkat akurasi terhadap hasil diagnosis.

3) Membutuhkan berbagai macam artikel yang terkait dengan penyakit HIV/AIDS. 
c. Analisis Kebutuhan Sistem

Sistem yang dibuat merupakan sistem pakar berbasis web. Untuk mengimplementasikan sistem pakar tersebut, terdapat beberapa hal yang perlu disiapkan yaitu:

1) Laptop Asus A455L.

2) Sistem Operasi Windows 10.

3) XAMPP Control Panel.

4) Text Editor Visual Studio Code.

5) Web Browser Google Chrome.

6) Web Hosting untuk publikasi sistem pakar yang telah dibuat.

\section{Akuisisi Pengetahuan}

Beberapa hal yang dilakukan pada tahap akuisisi pengetahuan antara lain adalah proses pengumpulan data, representasi pengetahuan, dan certainty factor.

a. Pengumpulan Data

Proses pengumpulan data pada penelitian ini dilakukan dengan cara melakukan wawancara dan dengan melakukan studi literatur. Berdasarkan hasil wawancara yang telah dilakukan terhadap pakar, diperoleh stadium HIV/AIDS yang akan disajikan pada tabel 1 yang disertai dengan kode untuk memudahkan pada saat implementasi sistem pakar.

Tabel 1. Stadium HIV/AIDS

\begin{tabular}{lc}
\hline Kode & Stadium \\
\hline S001 & Stadium 1 \\
\hline S002 & Stadium 2 \\
\hline S003 & Stadium 3 \\
\hline S004 & Stadium 4/AIDS \\
\hline
\end{tabular}

Berdasarkan proses wawancara yang telah dilakukan, diperoleh data mengenai berbagai macam gejala yang sering muncul pada saat seseorang terkena penyakit HIV/AIDS. Terdapat 20 gejala yang mungkin dialami oleh penderita HIV/AIDS yang akan disajikan pada tabel 2 berikut ini:

Tabel 2. Gejala HIV/AIDS

\begin{tabular}{ll}
\hline Kode & \multicolumn{1}{c}{ Gejala } \\
\hline \multirow{3}{*}{ Ke1 } & $\begin{array}{l}\text { Kelompok resiko tinggi (seks bebas, } \\
\text { pekerja seks(PS), gay, waria, pelanggan }\end{array}$ \\
& $\begin{array}{l}\text { PS, pengguna narkoba suntik, anak } \\
\text { punk) }\end{array}$ \\
\hline
\end{tabular}

\begin{tabular}{|c|c|}
\hline G02 & $\begin{array}{l}\text { Pasangan kelompok resiko tinggi/ } \\
\text { pasangan ODHA }\end{array}$ \\
\hline G03 & Memiliki garis keturunan HIV/AIDS \\
\hline G04 & $\begin{array}{l}\text { Suntik, tato, tindik menggunakan alat } \\
\text { yang tidak steril }\end{array}$ \\
\hline G05 & $\begin{array}{l}\text { Terjadi penurunan berat badan tanpa } \\
\text { sebab lebih dari } 10 \% \text { dari BB semula }\end{array}$ \\
\hline G06 & $\begin{array}{l}\text { Terjadi penurunan berat badan tanpa } \\
\text { sebab kurang dari } 10 \% \text { dari BB semula }\end{array}$ \\
\hline G07 & $\begin{array}{l}\text { Sering berkeringat pada malam hari } \\
\text { tanpa sebab dalam jangka waktu yang } \\
\text { lama }\end{array}$ \\
\hline G08 & $\begin{array}{l}\text { Terjadi pembengkakan kelenjar tanpa } \\
\text { sebab }\end{array}$ \\
\hline G09 & $\begin{array}{l}\text { Lelah/lesu secara berkelanjutan tanpa } \\
\text { diketahui penyebabnya }\end{array}$ \\
\hline G10 & $\begin{array}{l}\text { Timbul luka disekitar mulut dan } \\
\text { sariawan yang terus berulang }\end{array}$ \\
\hline G11 & $\begin{array}{l}\text { Muncul bintil berisi air pada tubuh dan } \\
\text { terasa nyeri dalam waktu yang lama } \\
\text { (herpes zoster) }\end{array}$ \\
\hline G12 & $\begin{array}{l}\text { Mengalami infeksi saluran pernafasan } \\
\text { yang terus berulang (sinusitis, tonsilitis, } \\
\text { otitis media, faringitis) }\end{array}$ \\
\hline G13 & $\begin{array}{l}\text { Mengalami anemia tanpa diketahui } \\
\text { penyebabnya }\end{array}$ \\
\hline G14 & $\begin{array}{l}\text { Muncul bercak putih pada rongga mulut, } \\
\text { kemerahan, perasaan seperti kapas di } \\
\text { mulut, nyeri saat makan atau menelan, } \\
\text { dan adanya retak atau kemerahan di } \\
\text { sudut mulut (oral hairy leukoplakia). }\end{array}$ \\
\hline G15 & $\begin{array}{l}\text { Demam tanpa sebab selama lebih dari } 1 \\
\text { bulan }\end{array}$ \\
\hline G16 & $\begin{array}{l}\text { Diare kronis yang berlangsung lebih dari } \\
1 \text { bulan }\end{array}$ \\
\hline G17 & $\begin{array}{l}\text { Sering mengalami batuk berdarah (TB } \\
\text { Paru) }\end{array}$ \\
\hline G18 & $\begin{array}{l}\text { Mengalami gangguan syaraf (kesulitan } \\
\text { berkonsentrasi/hilang ingatan) }\end{array}$ \\
\hline G19 & $\begin{array}{llr}\begin{array}{l}\text { Nyeri pada } \\
\text { berkelanjutan } \\
\text { penyebabnya }\end{array} & \begin{array}{l}\text { sendi/otot } \\
\text { tanpa }\end{array} & \text { secara } \\
\text { diketahui }\end{array}$ \\
\hline $\mathrm{G} 20$ & Mudah memar/berdarah tanpa sebab \\
\hline
\end{tabular}

Tabel 3 merupakan tabel yang berisi hubungan atau relasi yang terjadi diantara setiap gejala penyakit HIV/AIDS dengan stadium HIV/AIDS. Tabel di bawah ini bertujuan untuk mengetahui gejala yang dialami pada tiap stadium yang berbeda.

Tabel 3. Relasi Gejala dengan Stadium HIV/AIDS

\begin{tabular}{ccccc}
\hline Kode Gejala & \multicolumn{4}{c}{ Kode Stadium } \\
\cline { 2 - 5 } & S001 & S002 & S003 & S004 \\
\hline G01 & $\sqrt{ }$ & $\sqrt{ }$ & $\sqrt{ }$ & $\sqrt{ }$ \\
\hline G02 & $\sqrt{ }$ & $\sqrt{ }$ & $\sqrt{ }$ & $\sqrt{ }$ \\
\hline G03 & $\sqrt{ }$ & $\sqrt{ }$ & $\sqrt{ }$ & $\sqrt{ }$ \\
\hline
\end{tabular}




\begin{tabular}{|c|c|c|c|c|}
\hline G04 & $\sqrt{ }$ & $\sqrt{ }$ & $\sqrt{ }$ & $\sqrt{ }$ \\
\hline G05 & & & $\sqrt{ }$ & $\sqrt{ }$ \\
\hline G06 & & $\sqrt{ }$ & & \\
\hline G07 & & & & $\sqrt{ }$ \\
\hline G08 & & & $\sqrt{ }$ & \\
\hline G09 & & & $\sqrt{ }$ & $\sqrt{ }$ \\
\hline G10 & & $\sqrt{ }$ & & \\
\hline G11 & & $\sqrt{ }$ & $\sqrt{ }$ & $\sqrt{ }$ \\
\hline G12 & & $\sqrt{ }$ & $\sqrt{ }$ & $\sqrt{ }$ \\
\hline G13 & & & $\sqrt{ }$ & \\
\hline G14 & & & $\sqrt{ }$ & $\sqrt{ }$ \\
\hline G15 & & & $\sqrt{ }$ & $\sqrt{ }$ \\
\hline G16 & & & $\sqrt{ }$ & $\sqrt{ }$ \\
\hline G17 & & & & $\sqrt{ }$ \\
\hline G18 & & & & $\sqrt{ }$ \\
\hline G19 & & & & $\sqrt{ }$ \\
\hline G20 & & & & $\sqrt{ }$ \\
\hline
\end{tabular}

b. Representasi Pengetahuan

Semua data yang telah terkumpul direpresentasikan menggunakan kaidah produksi untuk memberikan gambaran dalam bentuk IF-THEN yang akan berguna untuk proses penalaran. Kaidah produksi dari data yang telah dikumpulkan dapat dilihat pada tabel 4 berikut ini:

Tabel 4. Kaidah Produksi

\begin{tabular}{|c|c|}
\hline Rule & $\begin{array}{l}\text { Kaidah Produksi } \\
\end{array}$ \\
\hline 1 & $\begin{array}{l}\text { IF G01 AND G02 AND G03 AND G04 } \\
\text { THEN S001 }\end{array}$ \\
\hline 2 & $\begin{array}{l}\text { IF G01 AND G02 AND G03 AND G04 } \\
\text { AND G06 AND G10 AND G11 AND } \\
\text { G12 THEN S002 }\end{array}$ \\
\hline 3 & $\begin{array}{l}\text { IF G01 AND G02 AND G03 AND G04 } \\
\text { AND G05 AND G08 AND G09 AND } \\
\text { G11 AND G12 AND G13 AND G14 } \\
\text { AND G15 AND G16 THEN S003 }\end{array}$ \\
\hline 4 & $\begin{array}{l}\text { IF G01 AND G02 AND G03 AND G04 } \\
\text { AND G05 AND G07 AND G09 AND } \\
\text { G11 AND G12 AND G14 AND G15 } \\
\text { AND G16 AND G17 AND G18 AND } \\
\text { G19 AND G20 THEN S004 }\end{array}$ \\
\hline
\end{tabular}

\section{c. Metode Certainty Factor}

Untuk memperoleh nilai certainty factor pakar dari setiap gejala, pada penelitian ini menggunakan tabel uncertain term yang akan disajikan pada tabel 5 .
Tabel 5. Interpretasi Nilai Certainty Factor Pakar

\begin{tabular}{lc}
\hline \multicolumn{1}{c}{ Uncertain Term } & Nilai CF \\
\hline Definitely Not (Pasti Tidak) & -1.0 \\
\hline $\begin{array}{l}\text { Almost Certainly Not (Hampir } \\
\text { Pasti Tidak) }\end{array}$ & -0.8 \\
\hline $\begin{array}{l}\text { Probably Not (Kemungkinan } \\
\text { Besar Tidak) }\end{array}$ & -0.6 \\
\hline Maybe Not (Mungkin Tidak) & -0.4 \\
\hline Unknown (Tidak Tahu) & -0.2 to 0.2 \\
\hline Maybe (Mungkin) & 0.4 \\
\hline Probably (Kemungkinan Besar) & 0.6 \\
\hline Almost Certainly (Hampir Pasti) & 0.8 \\
\hline Definitely (Pasti) & 1 \\
\hline Sumber: Apriliani \& Mustafidah, 2017 &
\end{tabular}

Berdasarkan nilai uncertain term yang telah disajikan pada tabel 5, maka dilakukan wawancara untuk mengetahui interpretasi pakar terhadap setiap gejala, kemudian mengubah interpretasi pakar tersebut menjadi nilai certainty factor seperti yang terlihat pada tabel 6 .

Tabel 6. Nilai CF Gejala HIV/AIDS

\begin{tabular}{ccccc}
\hline \multirow{2}{*}{ Kode Gejala } & \multicolumn{5}{c}{ Nilai CF tiap Stadium } \\
\cline { 2 - 5 } & S001 & S002 & S003 & S004 \\
\hline G01 & 0.8 & 0.8 & 0.8 & 0.8 \\
\hline G02 & 0.6 & 0.6 & 0.6 & 0.6 \\
\hline G03 & 0.4 & 0.4 & 0.4 & 0.4 \\
\hline G04 & 0.4 & 0.4 & 0.4 & 0.4 \\
\hline G05 & - & - & 0.6 & 0.6 \\
\hline G06 & - & 0.4 & - & - \\
\hline G07 & - & - & - & 0.2 \\
\hline G08 & - & - & 0.6 & - \\
\hline G09 & - & - & 0.4 & 0.4 \\
\hline G10 & - & 0.4 & - & - \\
\hline G11 & - & 0.4 & 0.4 & 0.4 \\
\hline G12 & - & 0.4 & 0.4 & 0.4 \\
\hline G13 & - & - & 0.4 & - \\
\hline G14 & - & - & 0.6 & 0.6 \\
\hline G15 & - & - & 0.6 & 0.6 \\
\hline G16 & - & - & 0.6 & 0.6 \\
\hline G17 & - & - & - & 0.4 \\
\hline G18 & - & - & - & 0.6 \\
\hline G19 & - & - & - & 0.6 \\
\hline G20 & - & - & - & 0.4 \\
\hline
\end{tabular}

Berikut ini adalah perhitungan manual untuk menghitung tingkat kepercayaan pakar terhadap stadium 1 HIV/AIDS:

CFCombine $=C F_{1}+C F_{2} *\left(1-C F_{1}\right)$

$C F_{1,2}=0,8+0,6 *(1-0,8)$

$C F_{1,2}=0,8+0,6 * 0,2$

$C F_{1,2}=0,8+0,12=0,92_{\text {old }^{1}}$ 
$C F_{\text {old }^{1}, 3}=0,92+0,4 *(1-0,92)$

$C F_{\text {old }^{1}, 3}=0,92+0,4 * 0,08$

$C F_{\text {old }^{1}, 3}=0,92+0,032=0,952_{\text {old }^{2}}$

$C F_{\text {old }}^{2}, 4=0,952+0,4 *(1-0,952)$

$C F_{\text {old }}^{2}, 4=0,952+0,4 * 0,048$

$C F_{\text {old }^{2}, 4}=0,952+0,0192=0,9712_{\text {old }^{3}}$

Dari perhitungan yang dilakukan secara manual tersebut maka dapat diketahui bahwa tingkat kepercayaan pakar terhadap stadium 1 HIV/AIDS yaitu sebesar 0,9712 atau $97,1 \%$.

\section{d. Alur Kerja Sistem Pakar}

Sistem pakar ini menggunakan metode forward chaining untuk melakukan penalaran berdasarkan gejala yang dimasukan oleh pengguna, dan menggunakan metode certainty factor untuk menghitung tingkat kepercayaan pakar terhadap hasil diagnosis yang diberikan oleh sistem. Alur kerja sistem pakar dapat dilihat pada gambar 2 .

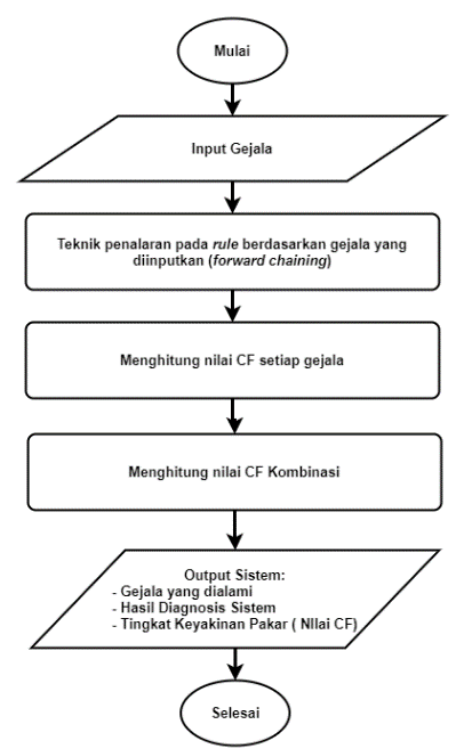

Gambar 2. Alur Kerja Sistem Pakar

\section{Perancangan}

Tahap perancangan terdiri dari tiga proses, yaitu pembuatan desain arsitektur aplikasi, desain arsitektur interface, dan implementasi.

a. Desain Arsitektur Aplikasi
Pada proses ini dilakukan pembuatan rancangan arsitektur aplikasi dengan diagram UML. Beberapa diagram yang dibuat pada tahap ini antara lain adalah:

1) Use Case Diagram

Use case diagram berfungsi untuk memberikan visualisasi mengenai hubungan yang terjadi antara aktor dengan sistem (Voutama \& Novalia, 2021).

2) Activity Diagram

Activity diagram menggambarkan berbagai macam aktivitas yang dapat dilakukan oleh user terhadap sistem pakar (Voutama \& Novalia, 2021). Gambar 3 adalah contoh activity

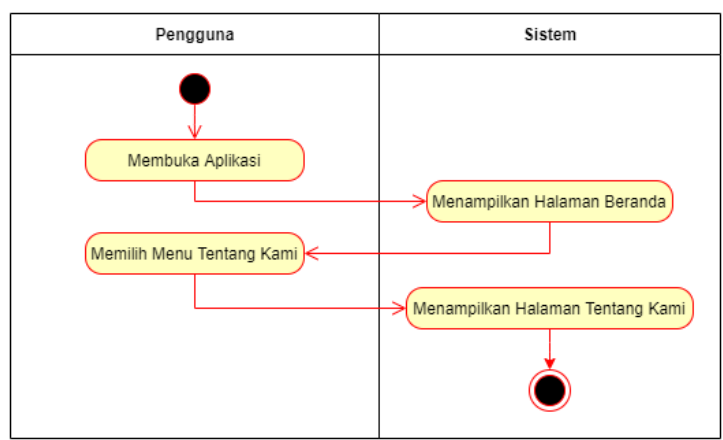

diagram yang telah dibuat:

Gambar 3. Activity Diagram Menu Tentang Kami

3) Sequence Diagram

Sequence diagram berguna untuk menampilkan urutan interaksi yang terjadi antar objek sehingga menghasilkan sebuah output yang diinginkan. Gambar 4 berikut ini merupakan contoh sequence diagram dari sistem pakar deteksi dini HIV/AIDS yang berisi urutan interaksi yang akan terjadi pada saat pengguna ingin melihat isi/detail dari sebuah artikel yang terdapat pada sistem pakar deteksi dini HIV/AIDS. 


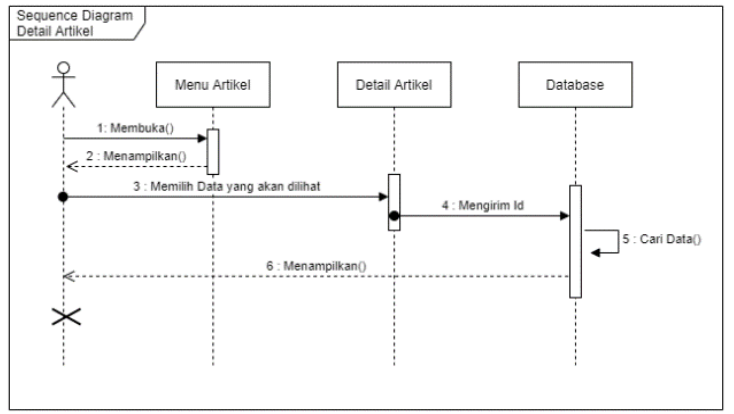

Gambar 4. Sequence Diagram Detail Artikel

4) Class Diagram

Class diagram merupakan diagram yang digunakan untuk memberikan visualisasi mengenai struktur yang terdapat di dalam sebuah sistem dengan memberikan gambaran dari setiap kelas dengan disertai dengan relasi yang terjadi antara satu kelas dengan kelas yang lainnya.

\section{b. Desain Arsitektur Interface}

Proses yang dilakukan pada tahap ini adalah membuat desain struktur tampilan antarmuka dari setiap halaman yang terdapat pada sistem pakar deteksi dini HIV/AIDS. Pada tahap ini semua tampilan baik dari segi admin ataupun pengguna akan dibuat desainnya dengan menggunakan aplikasi balsamiq wireframes.

Gambar 5 dan 6 merupakan contoh desain interface dari sistem pakar deteksi dini HIV/AIDS.

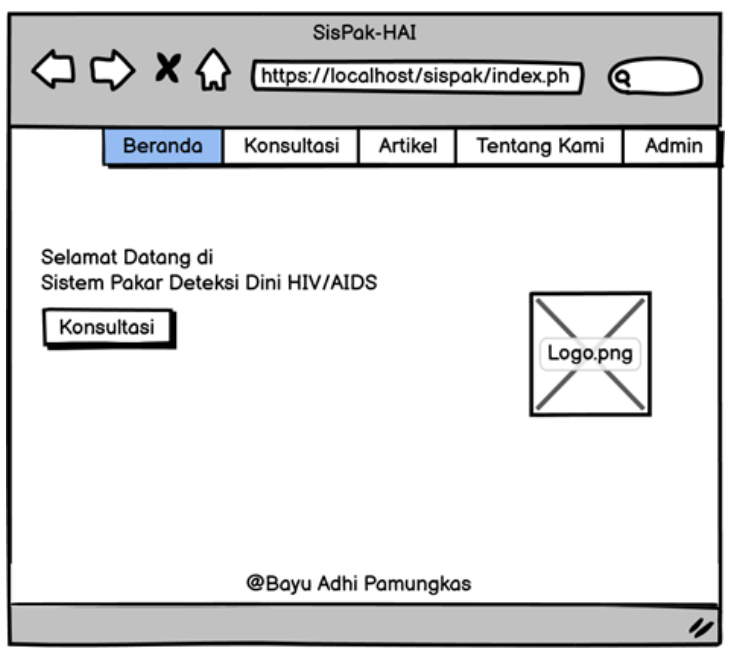

Gambar 5. Desain Interface Halaman Beranda
Gambar 6 merupakan hasil desain interface halaman anggota yang hanya dapat diakses oleh admin.

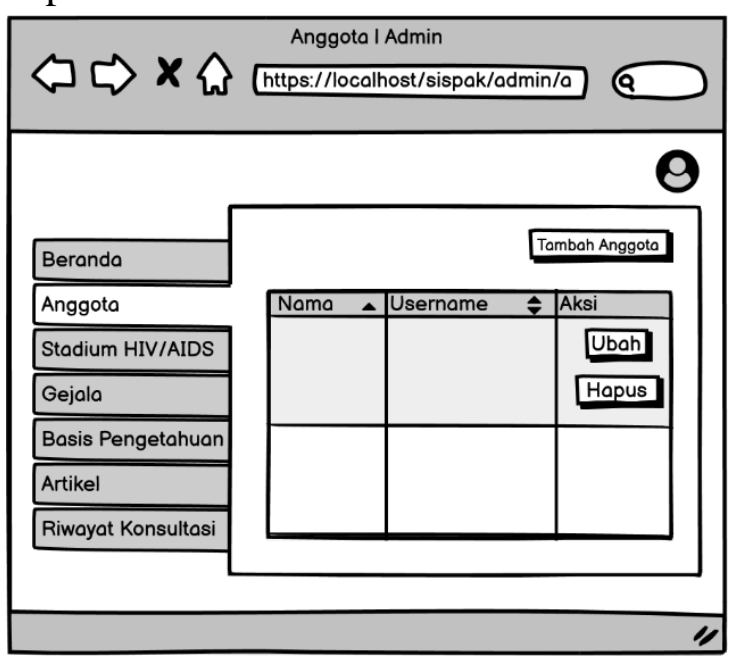

Gambar 6. Desain Interface Halaman Anggota (Admin)

c. Implementasi

Pada tahap ini proses yang dilakukan adalah mengimplementasikan desain yang telah dibuat ke dalam bahasa pemrograman. Bahasa yang digunakan pada sistem pakar ini adalah bahasa pemrograman PHP karena sistem pakar ini dibuat berbasis web. Gambar 7 merupakan hasil implementasi dari halaman beranda yang akan terbuka pertama kali pada saat pengguna membuka sistem pakar deteksi dini HIV/AIDS.

Gambar 7. Implementasi Halaman Beranda

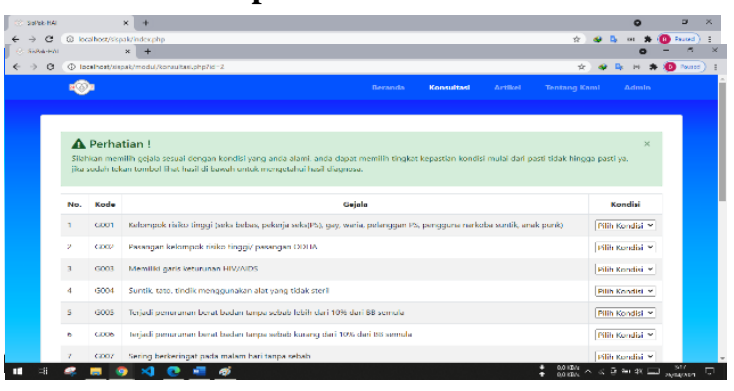

Gambar 8. Implementasi Halaman Konsultasi

Gambar 8 menunjukan halaman konsultasi yang digunakan oleh pengguna untuk melakukan konsultasi dengan cara mengisi kondisi berdasarkan gejala yang dialami.

\section{Pengujian}

Setelah sistem berhasil diimplementasikan, langkah selanjutnya 
adalah melakukan pengujian untuk mengetahui berbagai macam kesalahan yang ada pada sistem pakar tersebut. Beberapa pengujian yang dilakukan pada penelitian ini antara lain adalah:

\section{a. Black Box Testing}

Black box testing merupakan pengujian yang hanya melakukan pengujian dari segi tampilan tanpa memperhatikan kode pemrograman. Tabel 7 merupakan hasil pengujian black box testing yang dilakukan pada halaman beranda dimana hasil pengujian menunjukan bahwa respon sistem telah sesuai dengan harapan.

Tabel 7. Black Box Testing Halaman Beranda

\begin{tabular}{|c|c|c|c|}
\hline Pengujian & $\begin{array}{l}\text { Hasil yang } \\
\text { diharapkan }\end{array}$ & $\begin{array}{l}\text { Respon } \\
\text { Sistem }\end{array}$ & $\begin{array}{l}\text { Kesimp } \\
\text { ulan }\end{array}$ \\
\hline $\begin{array}{l}\text { Memilih } \\
\text { menu } \\
\text { beranda }\end{array}$ & $\begin{array}{l}\text { Sistem } \\
\text { menampilkan } \\
\text { halaman } \\
\text { beranda }\end{array}$ & $\begin{array}{l}\text { Sesuai } \\
\text { harapan }\end{array}$ & Diterima \\
\hline $\begin{array}{l}\text { Memilih } \\
\text { tombol } \\
\text { konsultasi }\end{array}$ & $\begin{array}{l}\text { Sistem } \\
\text { menampilkan } \\
\text { form } \\
\text { konsultasi }\end{array}$ & $\begin{array}{l}\text { Sesuai } \\
\text { harapan }\end{array}$ & Diterima \\
\hline $\begin{array}{l}\text { Memilih } \\
\text { menu } \\
\text { konsultasi }\end{array}$ & $\begin{array}{l}\text { Sistem } \\
\text { menampilkan } \\
\text { form } \\
\text { konsultasi }\end{array}$ & $\begin{array}{l}\text { Sesuai } \\
\text { harapan }\end{array}$ & Diterima \\
\hline $\begin{array}{l}\text { Memilih } \\
\text { menu } \\
\text { artikel }\end{array}$ & $\begin{array}{l}\text { Sistem } \\
\text { menampilkan } \\
\text { halaman } \\
\text { artikel }\end{array}$ & $\begin{array}{l}\text { Sesuai } \\
\text { harapan }\end{array}$ & Diterima \\
\hline $\begin{array}{l}\text { Memilih } \\
\text { menu } \\
\text { tentang } \\
\text { kami }\end{array}$ & $\begin{array}{l}\text { Sistem } \\
\text { menampilkan } \\
\text { halaman } \\
\text { tentang kami }\end{array}$ & $\begin{array}{l}\text { Sesuai } \\
\text { harapan }\end{array}$ & Diterima \\
\hline $\begin{array}{l}\text { Memilih } \\
\text { menu } \\
\text { admin }\end{array}$ & $\begin{array}{l}\text { Sistem } \\
\text { menampilkan } \\
\text { form log in }\end{array}$ & $\begin{array}{l}\text { Sesuai } \\
\text { harapan }\end{array}$ & Diterima \\
\hline
\end{tabular}

\section{b. User Acceptance Test}

User acceptance test merupakan pengujian yang dilakukan untuk mengetahui respon pengguna terhadap sistem pakar yang telah dibuat. Metode yang digunakan yaitu dengan membagikan kuesioner secara online terhadap 50 pengguna yang berisi 5 pertanyaan terkait tampilan, dan 5 pertanyaan terkait manfaat dengan menggunakan skala likert. Tabel 8 merupakan bobot nilai yang terdapat pada skala likert:
Tabel 8. Bobot Nilai Skala Likert

\begin{tabular}{lc}
\hline \multicolumn{1}{c}{ Jawaban } & Bobot \\
\hline Sangat Tidak Setuju (STS) & 1 \\
\hline Tidak Setuju (TS) & 2 \\
\hline Netral (N) & 3 \\
\hline Setuju (S) & 4 \\
\hline Sangat Setuju (SS) & 5 \\
\hline Sumber: Rudi Supriatna, 2018 &
\end{tabular}

Setelah kuesioner disebarkan kepada pengguna, maka diperoleh hasil kuesioner yang telah diolah dengan frekuensi jumlah jawaban yang akan ditampilkan pada tabel 9 berikut ini:

Tabel 9. Hasil Kuesioner

\begin{tabular}{ccccccc}
\hline \multirow{2}{*}{ Pertanyaan } & \multicolumn{5}{c}{ Frekuensi Jawaban } \\
\cline { 2 - 7 } & & STS & TS & N & S & SS \\
\hline \multirow{5}{*}{ Tampilan } & 0 & 1 & 6 & 33 & 10 \\
\cline { 2 - 7 } & 2 & 0 & 1 & 3 & 31 & 15 \\
\cline { 2 - 7 } & 3 & 0 & 0 & 6 & 31 & 13 \\
\cline { 2 - 7 } & 4 & 0 & 1 & 7 & 29 & 13 \\
\cline { 2 - 7 } & 5 & 0 & 0 & 6 & 32 & 12 \\
\hline Jumlah & & 0 & 3 & 28 & 156 & 63 \\
\hline \multirow{5}{*}{ Manfaat } & 1 & 0 & 2 & 6 & 29 & 13 \\
\cline { 2 - 7 } & 2 & 0 & 0 & 10 & 27 & 13 \\
\cline { 2 - 7 } & 3 & 0 & 0 & 12 & 25 & 13 \\
\cline { 2 - 7 } & 4 & 0 & 1 & 8 & 27 & 14 \\
\cline { 2 - 7 } & 5 & 0 & 0 & 3 & 28 & 19 \\
\hline Jumlah & 0 & 3 & 39 & 136 & 72 \\
\hline
\end{tabular}

Hasil frekuensi jawaban dari kuesioner digunakan untuk menghitung total skor dari segi tampilan dan segi manfaat dengan cara menghitung jumlah frekuensi dari setiap nilai skala likert kemudian dikalikan dengan bobot nilai dari setiap jawaban sehingga diperoleh hasil seperti yang terlihat pada tabel 10 .

Tabel 10. Total Skor dari Segi Tampilan dan Segi Manfaat

\begin{tabular}{|c|c|c|c|c|}
\hline Pertanyaan & Nilai & Jumlah & Bobot & $\begin{array}{l}\text { Jumlah } \\
* \text { Bobot }\end{array}$ \\
\hline \multirow{5}{*}{ Tampilan } & STS & 0 & 1 & 0 \\
\hline & TS & 3 & 2 & 6 \\
\hline & $\mathrm{N}$ & 28 & 3 & 84 \\
\hline & $\mathrm{S}$ & 156 & 4 & 624 \\
\hline & SS & 63 & 5 & 315 \\
\hline \multicolumn{4}{|c|}{ Total Skor } & 1029 \\
\hline \multirow{4}{*}{ Manfaat } & STS & 0 & 1 & 0 \\
\hline & TS & 3 & 2 & 6 \\
\hline & $\mathrm{N}$ & 39 & 3 & 117 \\
\hline & $\mathrm{S}$ & 136 & 4 & 544 \\
\hline
\end{tabular}




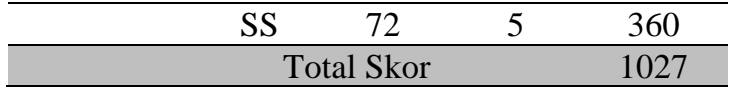

Setelah total skor dari segi tampilan dan manfaat diketahui, langkah selanjutnya adalah menghitung persentase dari segi tampilan dan segi manfaat. Untuk menghitung persentase tersebut maka kita perlu menghitung nilai maksimum untuk pertanyaan tersebut dengan cara berikut:

Nilai Max = Jumlah Responden * Jumlah Pertanyaan

* Bobot Maksimum

Nilai Max $=50 * 5 * 5$

Nilai Max $=1250$

Setelah nilai maksimum diketahui, maka langkah selanjutnya adalah menghitung persentase dari segi tampilan dan manfaat dengan cara berikut:

1) Persentase Tampilan

$$
\begin{aligned}
\text { Persentase } & =\frac{\text { Total Skor }}{\text { Nilai Max }} * 100 \% \\
\text { Persentase } & =\frac{1029}{1250} * 100 \% \\
\text { Persentase } & =82,3 \%
\end{aligned}
$$

2) Persentase Manfaat

Persentase $=\frac{1027}{1250} * 100 \%$
Persentase $=82,2 \%$

Tabel 10. Kriteria Interpretasi Nilai

\begin{tabular}{cc}
\hline Persentase & Interpretasi Nilai \\
\hline $0 \%-20 \%$ & Sangat Lemah \\
\hline $21 \%-30 \%$ & Lemah \\
\hline $41 \%-60 \%$ & Cukup \\
\hline $61 \%-80 \%$ & Kuat \\
\hline $81 \%-100 \%$ & Sangat Kuat \\
\hline
\end{tabular}

Sumber: Rudi Supriatna, 2018

Berdasarkan hasil perhitungan persentase yang telah dilakukan maka dapat diketahui bahwa tanggapan dari responden dari terhadap sistem pakar deteksi dini HIV/AIDS dari segi tampilan dan segi manfaat berdasarkan tingkat penerimaan adalah sangat kuat, hal ini sesuai dengan teori yang disajikan dalam tabel 11 dimana apabila persentase nilai berada diatas $80 \%$ maka interpretasi nilai yang dihasilkan adalah sangat kuat.

\section{Dokumentasi}

Berikut ini adalah cara untuk melakukan konsultasi pada sistem pakar deteksi dini HIV/AIDS.

a. Buka aplikasi sistem pakar deteksi dini HIV/AIDS pada browser yang terdapat di perangkat masing-masing.

b. Pada saat aplikasi sudah terbuka, maka tampilan awal sistem adalah halaman beranda, gambar 9 adalah tampilan halaman beranda.

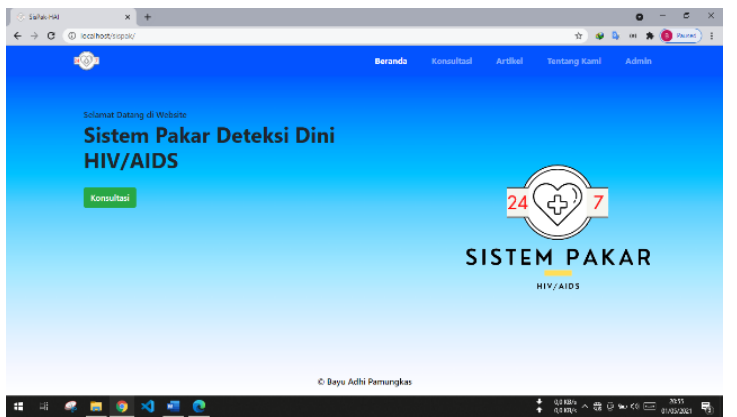

Gambar 9. Tampilan Halaman Beranda

c. Cara untuk mengakses halaman konsultasi adalah dengan menekan tombol konsultasi yang terdapat pada halaman beranda atau dengan menekan menu konsultasi yang terdapat pada bagian atas seperti yang terlihat pada gambar 10.

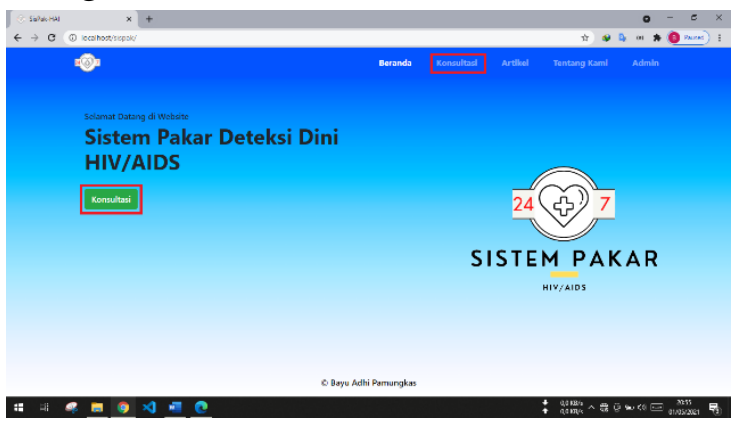

Gambar 10. Tombol Konsultasi

d. Setelah menu konsultasi terbuka, langkah selanjutnya adalah mengisi form konsultasi seperti pada gambar 11 kemudian menekan tombol selanjutnya. Gambar 11. Tampilan Form Konsultasi

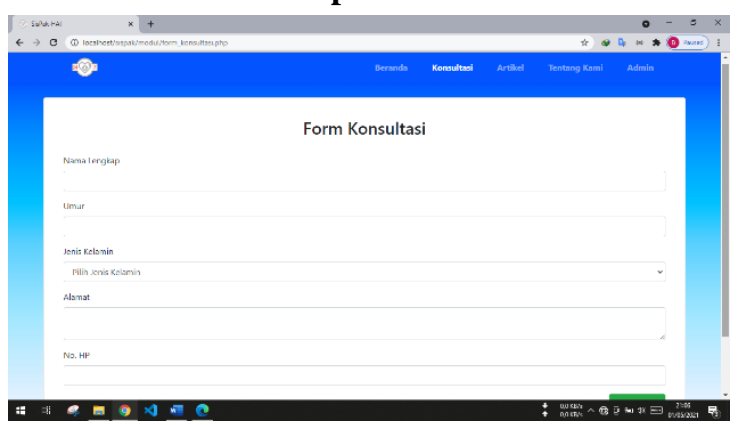


e. Setelah itu pengguna mengisi kondisi berdasarkan dengan gejala yang dialami dan menekan tombol lihat hasil Halaman konsultasi dapat dilihat pada gambar 12 .

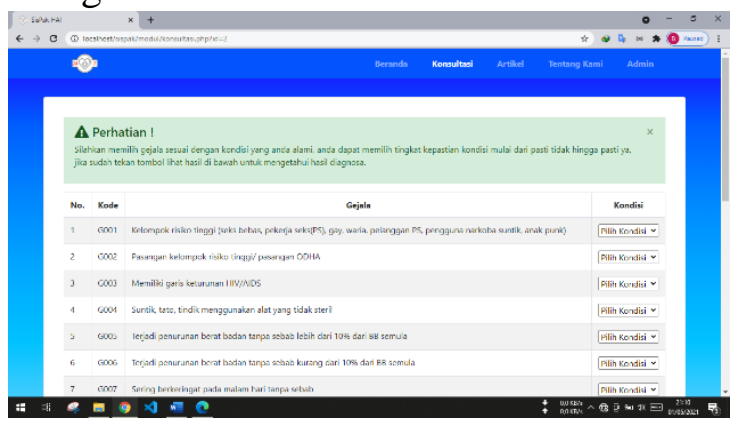

Gambar 12. Tampilan Halaman Konsultasi

f. Setelah pengguna menekan tombol lihat hasil maka sistem akan menampilkan halaman hasil konsultasi.

\section{SIMPULAN}

Berdasarkan penelitian yang telah dilakukan, dapat diambil kesimpulan sebagai berikut:

1. Perancangan sistem pakar deteksi dini HIV/AIDS dilakukan dengan menggunakan metode Expert System Development Life Cycle (ESDLC) yang terdiri dari tahap penilaian, akuisisi pengetahuan, perancangan, pengujian, serta dokumentasi.

2. Sistem pakar deteksi dini HIV/AIDS diimplementasikan berbasis web dengan menggunakan bahasa pemrograman PHP serta basis data MySQL. Metode yang digunakan pada sistem pakar ini adalah metode forward chaining sebagai mesin inferensi, serta metode certainty factor untuk menghitung nilai keyakinan pakar terhadap hasil diagnosis yang diberikan oleh sistem.

3. Proses evaluasi sistem pakar dilakukan dengan menggunakan beberapa cara, diantaranya black box testing dan user acceptance test. Hasil dari black box testing menunjukan bahwa sistem berjalan dengan baik, kemudian hasil user acceptance test yang dilakukan menunjukan penilaian dari segi tampilan memiliki persentase $82,3 \%$, dan dari segi manfaat memiliki persentase sebesar $82,2 \%$, artinya sistem dapat diterima oleh masyarakat dengan interpretasi sangat kuat.

\section{DAFTAR PUSTAKA}

Akil, I. (2017). Analisa Efektifitas Metode Forward Chaining dan Backward Chaining pada Sistem Pakar. Jurnal Pilar Nusa Mandiri, 13(1), 35-42.

Apriliani, P. F., \& Mustafidah, H. (2017). Implementasi Certainty Factor Pada Diagnosa Penyakit Infeksi Tropis. Jurnal Riset Sains Dan Teknologi, 1(1), 22-36.

Direktur Jenderal P2P. (2020). Laporan Perkembangan HIV AIDS \& Penyakit Infeksi Menular Seksual (PIMS) Triwulan IV Tahun 2019. Kementerian Kesehatan RI.

Fajrin, M., \& Destiani, D. (2016). Perancangan Sistem Pakar Diagnosis Penyakit Kanker Mulut. Jurnal Algoritma, 12(2), 192-198. https://doi.org/10.33364/algoritma/v.1 2-2.192

Hayadi, B. H. (2016). SISTEM PAKAR (1st ed.). Deepublish.

Iskandar, D. (2017). Sistem Pakar Mendiagnosa Penyakit Tanaman Kol Menggunakan Metode Certainty Factor. Pelita Informatika Budi Darma, 16(1), 10-15. https://ejurnal.stmik-

budidarma.ac.id/index.php/pelita/artic le/download/247/231

Kementerian Kesehatan RI. (2020). Infodatin HIV AIDS. Pusat Data dan Informasi Kementerian Kesehatan RI (Pusdatin).

https://pusdatin.kemkes.go.id/resourc es/download/pusdatin/infodatin/infod atin-2020-HIV.pdf

Situmeang, B., Syarif, S., \& Mahkota, R. (2017). Hubungan Pengetahuan HIV / AIDS dengan Stigma terhadap Orang 
dengan HIV / AIDS di Kalangan Remaja 15-19 Tahun di Indonesia ( Analisis Data SDKI Tahun 2012 ). Jurnal Epidemiologi Kesehatan Indonesia, 1(2), 35-43. https://doi.org/http://dx.doi.org/10.74 54/epidkes.v1i2.1803

Supriatna, R. (2018). Implementasi Dan User Acceptance Test ( UAT) Terhadap Aplikasi E-Learning pada Madrasah Aliyah Negeri (MAN) 3 Kota Banda Aceh. Universitas Islam Negeri Ar-Raniry.

UNAIDS. (2020). UNAIDS DATA 2020. Joint United Nations Programme on HIV/AIDS.

https://www.unaids.org/sites/default/f iles/media_asset/2020_aids-databook_en.pdf

Voutama, A. (2018). Perancangan Aplikasi M-Discussion Berbasis Android Sebagai Wadah Diskusi Sekolah. Syntax: Jurnal Informatika, 7(2), 116124.

https://doi.org/https://doi.org/10.3570 6/syji.v7i2.1707

Voutama, A., \& Novalia, E. (2021). Perancangan Aplikasi M-Magazine Berbasis Android Sebagai Sarana Mading Sekolah Menengah Atas. Jurnal Tekno Kompak, 15(1), 104115.

https://doi.org/https://doi.org/10.3336 5/jtk.v15i1.920 